\title{
Stocking rate risk for pasture-fed steers under weather uncertainty
}

\author{
LUCAS D. PARSCH, MICHAEL P. POPP, AND OTTO J. LOEWER
}

Parsch is associate professor and Popp is assistant professor, Department of Agricultural Economics; Loewer is professor and dean of engineering, University of Arkansas, Fayetteville, Ark.

Abstract

A biophysical model, GRAZE, is used to simulate beef forage performance for stocker steers pastured on common bermudagrass. Eight alternative stocking rates, ranging from low to high grazing intensity, are simulated over 14 "states of nature" using historical weather data. The impact of weather variability on animal weight gain and economic performance is assessed and empirical cumulative distributions of net returns are developed. The risk efficient stocking rate strategies are identified for alternative decision-maker risk attitudes using generalized stochastic dominance. Under improved pasture conditions in Arkansas, results show that (a) expected weight gain per head is largely independent of grazing intensity until a critical stocking rate (6 hd/ha) is attained; (b) the highest expected net return per hectare is achieved under a lower stocking rate $(10 \mathrm{hd} / \mathrm{ha})$ than one which results in highest expected weight gain per hectare (12 hd/ha); and, (c) an increase in the stocking rate is accompanied by greater production (weather) risk which is reflected in increased variance of weight gain and net returns as well as a higher frequency and magnitude of economic losses.

Key Words: stocking rate, stocker steers, grazing management, economics, simulation, risk, stochastic dominance

A key decision variable for the manager of a stocker steer operation is to determine the appropriate stocking rate, i.e., the number of steers to graze per unit area of pasture. The relationship between stocking rate and the performance of pastured animals has been the subject of numerous studies, but because of a diversity of performance measures used by researchers in evaluating livestock/pasture systems, the implications for management are varied.

Published results of stocking rate studies by certain range, crop, and livestock researchers have focused on animal weight gain as a performance measure. Results of these studies show general agreement on 2 issues: (a) Low stocking rates result in the highest weight gain or average daily gain (ADG) per animal (Hubbard 1951, Halls 1957, Chapman et al.1972, Guerrero et al. 1984, Hart et al. 1988, Aiken and Bransby 1992) and, (b) an increase in the stocking rate to medium or high levels results in the maximum

Manuscript accepted 7 Jan. 1997.
Resúmen

EI modelo biofisico, GRAZE, es usado para simular el comportamiento de la relación carga-forraje en novillos pastoreando en pasto bermuda común. Ocho diferentes cargas animal, las cuales variaron desde baja carga animal hasta alta carga animal, fueron simuladas en 14 diferentes "estados de la naturaleza" usando como base información meteorológica previamente colectada. El impacto de la variabilidad en condiciones climáticas sobre la ganancia de peso y el comportamiento económico del modelo fueron estudiados y las distribuciones cumulativas empiricas de ganacia neta fueron desarrolladas. Las estrategias de riesgo-eficiencia de la carga animal fueron identificadas para las alternativas de riesgo en la toma de decisiones usando dominancia estocástica generalizada. Bajo condiciones de pastoreo mejoradas en Arkansas, los resultados mostraron que a) la ganancia esperada de peso por animal es independiente de la intensidad de pastoreo hasta que una carga animal critica (6 ua/ha) es alcanzada; b) la mas alta tasa de ganancia neta por hectarea es alcanzada bajo una carga animal baja (10 ua/ha) comparada con aquella que resulta de la mas alta ganancia de peso esperada por hectarea (12 ua/ha); y c) el incremento en la carga animal resulta en un mayor riesgo (clima adverso) en la producción el cual se refleja en un incremento en las varianzas de la ganacia de peso y ganacia neta asi como una mas alta frecuencia y magnitud de pérdidas ecónomicas.

weight gain per unit area of pasture (Hull et al. 1961, Hull et al. 1965, Bement 1969, Neville and McCormick 1976, Adjei et al. 1980, Willms et al. 1986, Bertelsen et al. 1993). Some researchers have modeled response surfaces of the relationships in (a) and/or (b) to enable determination of the stocking rate which results in either maximum weight gain per head or maximum weight gain per hectare (Harlan 1958, Riewe 1961, Riewe et al. 1961, Peterson et al. 1965, Hart 1972, Jones and Sandland 1974, Hart 1978, Hart et al. 1988, Conrad et al. 1981). Heitschmidt and Taylor (1991) as well as Holechek et al. (1995) provide a conceptual treatment of the trade-offs in weight gain per head versus per unit area of pasture. Hart (1993) furnishes evidence that empirical stocking rate research has clustered around several prominent "solidarity groups" which reflect 5 alternative shapes of weight gain response surfaces.

Empirical investigations into the economics of stocking rates have likewise resulted in general agreement that neither the high- 
est weight gain per animal (Pearson 1973, Hart 1978) nor the maximum weight gain per unit area of pasture provides maximum profits, but rather that the economic optimum for a typical set of price relationships exists at a stocking rate somewhere in between (Hildreth and Riewe 1963, Bement 1969, Hart 1972, Russell et al. 1981, Olowolayemo et al. 1992, Antoni et al. 1992). Workman (1986, p. 55) provides a comprehensive treatment of the economic issues related to the stocking rate issue.

One management issue which the above studies do not quantify is the weather risk associated with selecting a stocking rate. In a livestock/pasture system, the supply of herbage available to each animal $(\mathrm{kg} / \mathrm{hd})$ is a function of both the weather and the stocking rate. However, at the time the animals are placed onto pasture, the stocker steer producer cannot determine with certainty if rainfall over the grazing period will provide sufficient pasture growth to support the number of animals to be grazed. The continuum of possible "mismatches" between stocking rate and pasture availability in any one year is bounded by the following 2 extremes: Selection of a high stocking ratc in a "poor" weather ycar could result in reduced weight gain per hectare due to excessive competition between animals for a shortage of available pasture; by contrast, the choice of a low stocking rate in a "good" weather year might result in large weight gain per head due to highly selective grazing but low returns per hectare due to excess ungrazed forage.

Some empirical field studies have suggested that higher stocking rates result in greater risk for the producer (Harlan 1958, Willms et al. 1986, Knight et al. 1990). Often, however, researchers have used a modeling approach to address the issue of production and/or market risk in grazing systems. Examples of studies which have modeled the stocking decision using either bayesian decision analysis, simulation, dynamic programming, or optimal control include White and Eidman (1971), Curll (1978), Rodriguez and Taylor (1988), Riechers et al. (1989), Huffaker and Wilen (1991), Hart (1989), Torell et al. (1991), and Carande et al. (1995). Given the complexity of grazing systems and the stocking decision, Scarnecchia (1994) suggests that in order to "advance research on the multiple relationships of livestock grazing, computer based analyses. . .are needed."

The purpose of this paper is to evaluate the stocking rate decision under weather uncertainty using computer simulation. A biophysical computer model, GRAZE, is used to simulate the performance of stocker steers summer pastured on intensively managed common bermudagrass in western Arkansas under a range of alternative weather scenarios. For each stocking rate, confidence intervals and empirical cumulative distributions of net returns are developed which show the probability of attaining specified income levels. Each stocking rate strategy is ranked for trade-offs in risk and economic returns using stochastic dominance ordering. The application shows how the choice of stocking rate for a risk averse decision maker differs from the profit maximizer or the producer who attempts to maximize weight gain.

\section{Materials and Methods}

\section{Simulation Model}

GRAZE (Parsch and Loewer 1995) is a simulation model which permits evaluation of beef forage production as a function of both management and environmental variables. The GRAZE model consists of 3 major sub-components: a biophysical plant growth and composition model (Smith et al. 1985); a physiological feed intake and animal growth model (Loewer et al. 1985); and a plant-animal interface model which describes the logic of selective grazing as a function of the environment (Loewer et al. 1987). The plant sub-model simulates plant growth and quality as a function of daily climatological input data, soil moisture profile, crop growth parameters, forage removal rates, and fertilization data. The animal sub-model describes animal intake, growth, and response to the environment based on a set of input parameters which describes the composition of the animal in terms of chemical and physical measures. The interface model links the crop and animal sub-models by providing the rationale for grazing behavior: Grazing animals attempt to maximize the digestible dry matter intake rate which is influenced by the physiological weightage of the animal, forage quality, and availability.

The logic of the GRAZE model describes the interdependence between the animal and crop sub-systems. Animal growth rate and body composition are influenced by forage growth rate, availability, and quality. In turn, changes in the nutritional requirements of the grazing animal cause differential removal rates of herhage, which subsequently affect the quantity and quality of forage available. A specific beef forage management strategy is identified in the model through user inputs which define variables controlled by the livestock/pasture producer. These include the selection of the stocking rate, pasture genotype and fertility program, initial weight-age class of the animals, and grazing system (rotational or continuous). The simulation time increment is 1 day for the plant sub-model and 15 minutes for the animal logic. The model is driven by daily weather variables which define the environment in which the managed system operates.

Computer aspects and operation of the GRAZE model, including the design of simulation experiments and input data, are described in Parsch and Loewer (1995). Details of model development, biophysical relationships, and computational algorithms are described in the references cited above for the different model components. Case studies demonstrating the use and testing of GRAZE are sumularized in Loewer and Parsch (1995).

\section{Grazing System Experimental Design}

The simulation experiment was designed to evaluate summer grazing of stocker steer calves on grass pasture at Booneville, Arkansas (Logan County). Each scenario began with $226 \mathrm{~kg}$ steer calves placed onto common bermudagrass pasture on 1 June. For each scenario, crop growth simulation commenced sufficiently early (1 February) to permit growth of pasture before the 1 June stocking date. Levels of nitrogen applied to the pasture on 1 April and 15 June of each simulated year were $112 \mathrm{~kg} / \mathrm{ha} ; 1$ April applications of $\mathrm{P}_{2} \mathrm{O}_{5}$ and $\mathrm{K}_{2} \mathrm{O}$ were set at $112 \mathrm{~kg} / \mathrm{ha}$ and 336 $\mathrm{kg} / \mathrm{ha}$, respectively.

All steers were continuously pastured for a 126 day (18 week) summer grazing period. On 4 October of each year, the simulation was terminated and economic performance was assessed based on the immediate sale of the stocker steers at their simulated ending weights for each of the systems analyzed. Steers were sold before 4 October in any year only if weight loss during the grazing season exceeded $5 \%$ of the maximum gross body weight attained up to that point. Although the appropriate time to sell would be whenever the returns from additional weight gains no longer exceeded their cost, this $5 \%$ trigger could be severe in that 
the "economic" time to sell might occur before animals lose weight. However, this arbitrary "early sell" strategy was implemented in order to reduce potential losses whenever droughty conditions resulted in a severe decline in animal performance without-on the other hand-triggering a "premature" sale if expected returns fell only temporarily below costs.

Stocking rate was the sole manager-controlled input varied across simulation runs. Eight alternative stocking rates, ranging between 2 and $16 \mathrm{hd} / \mathrm{ha}$, were each simulated over alternative "states of nature," i.e., different weather scenarios over 14 years.

Fourteen years of daily historical weather data (maximum and minimum temperature, precipitation) at Booneville, Arkansas for the years 1972-1985 inclusive were used to simulate these alternative weather scenarios. The 14 year period exhibits growing season rainfall between $312 \mathrm{~mm}$ and $724 \mathrm{~mm}$ (Fig. 1). Rainfall distribution over the period of early season bermudagrass growth (May-June) for the 14 year period ranged between $98 \mathrm{~mm}$ and $351 \mathrm{~mm}$. Rainfall distribution over the months of July and August for the same period ranged between $15 \mathrm{~mm}$ and $293 \mathrm{~mm}$.

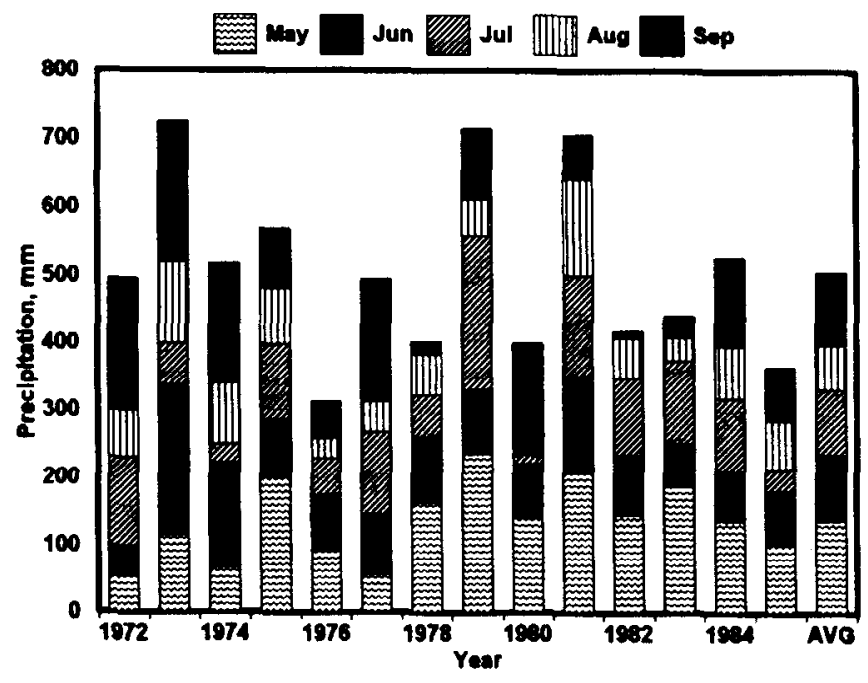

Fig. 1. Summer precipitation, pasture growing season, Booneville, Ark., 1972-1985.

At the beginning of the grazing season on the 1 June stocking date (week 0), 1980 and 1981 are representative of near normal years with only a small surplus of precipitation (Fig. 2). Midway through the grazing period, however, it becomes evident that 1980 and 1981 become, respectively, droughty and high rainfall seasons with an implicitly different potential to support pasture growth and stocker grazing. By contrast, 1977 begins as a droughty grazing season but returns to near normal precipitation levels in early July (week 5). Rainfall levels and forage condition on the 1 June stocking date may be poor indicators of the pasture's ability to support livestock throughout the projected grazing period. Based on survey data, Ruwan el al. (1994) showed that the factor which dominated the stocking rate decision was perceptions about weather. Thus, if perceptions about weather are misleading, then the likelihood for a mismatch between stocking rate and pasture potential may be high.

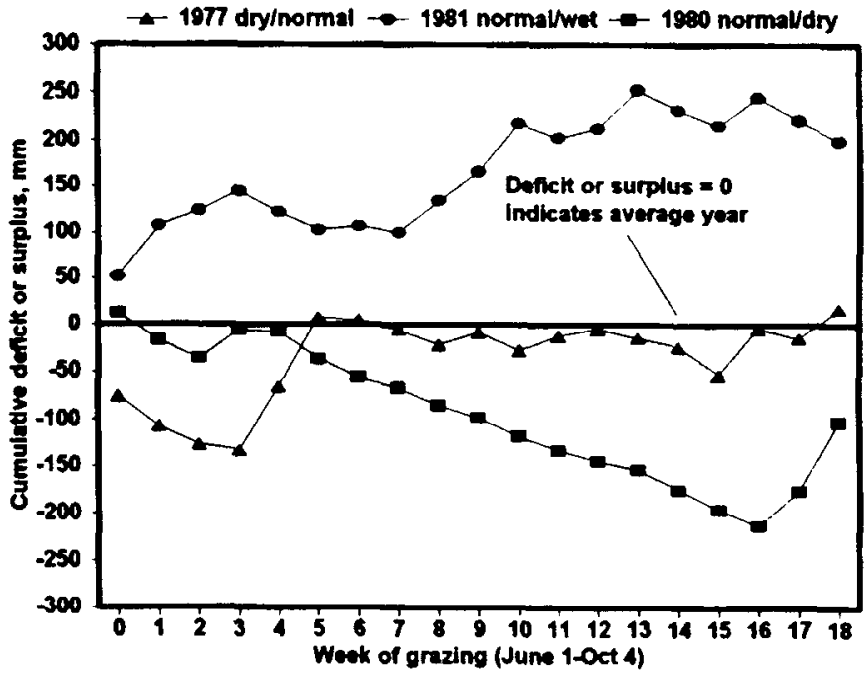

Fig. 2. Cumulative deficit or surplus precipitation for 3 selected years, Booneville, Ark.

\section{Economic Model}

GRAZE output for daily simulated animal empty body weight monitored at weekly intervals was used to calculate net returns for each of the 112 strategy years (14 years for each of 8 stocking rate strategies). As in Hildreth and Riewe (1963), net returns were defined as gross margin returns from the sale of the stocker animals minus selected marketing and production costs (commission, hauling, veterinary, interest, etc.) associated with each simulation scenario. The net economic return ( $\$ / \mathrm{ha}$ ) measures the dollar contribution to overhead labor, management, land, and overhead capital generated by each stocking rate strategy, i.e.,

$\mathrm{NR}=\mathrm{SRATE}\left\{\left[\left(\mathrm{PSELL}_{\mathrm{wc}} * \mathrm{WT}_{\mathrm{w}}\right) *(1-\mathrm{COM})\right]-\right.$ where:

$$
\left.\left[(\text { PBUY*WTBUY })+\mathrm{INT}_{\mathrm{w}}+\mathrm{CCOST}\right]\right\}
$$

$\begin{aligned} \text { NR } & =\text { net returns, } \$ / \mathrm{ha} \\ \text { SRATE } & \text { stocking rate, hd/ha } \\ \text { PSELL }_{\text {wc }} & =\text { stocker selling price for weight class c in } \\ & \text { week w, } \$ / \mathrm{kg} \\ \mathrm{WT}_{\mathrm{w}} & =\text { weight of steer in week w, } \mathrm{kg} / \mathrm{hd} \\ \mathrm{COM} & =\text { sales commission, } \$ / \$ \\ \text { PBUY } & =\text { stocker purchase price, } \$ / \mathrm{kg} \\ \mathrm{WTBUY} & =\text { weight of steer at purchase, } \mathrm{kg} / \mathrm{hd} \\ \mathrm{INT}_{\mathrm{w}} & =\text { cumulative interest charge in week } \mathrm{w}, \$ / \mathrm{hd} \\ \mathrm{CCOST} & =\text { miscellaneous per head carrying costs, } \$ / \mathrm{hd}\end{aligned}$

Gross receipts from the sale of the steers is the first term in parentheses in the above equation. Gross receipts are the product of simulated steer empty body weight at week $w\left(\mathrm{WT}_{\mathrm{w}}\right)$ and the market price received for weight class $c$ in week $w$ of simulation $\left(\right.$ PSELL $\left._{w c}\right)$. The market price received for the animals is the Arkansas auction (USDA-AMS) 13 year (1973-1985) June-October average price for No. 1 medium-frame steers indexed to 1995 price levels (Table 1). For each simulated animal ending weight, the actual selling price was determined by linearly interpolating between weight class categories in Table 1 to capture price differentials across weight categories. Subsequently, this price was multiplied by an index linearly interpolated between the relevant monthly indexes in Table 1 to convert to weekly prices. The 1973-1985 database of prices in Table 1 
Table 1. Monthly average price index and average price received for No. 1 , medium frame feeder steers ${ }^{1}$.

\begin{tabular}{|c|c|c|c|c|c|c|}
\hline \multirow{2}{*}{$\begin{array}{l}\text { Weight Class } \\
\text { (kg/hd) }\end{array}$} & \multicolumn{5}{|c|}{ Price Index } & \multirow{2}{*}{$\begin{array}{l}\text { Price } \\
\text { Received } \\
\text { (\$/kg) }\end{array}$} \\
\hline & Jun. & Jul. & Aug. & Sep. & Oet. & \\
\hline $181-227$ & 1.01 & 1.00 & 1.03 & 0.99 & 0.98 & 2.11 \\
\hline $227-272$ & 1.00 & 1.00 & 1.02 & 1.00 & 0.98 & 2.00 \\
\hline $272-317$ & 0.99 & 1.01 & 1.02 & 1.00 & 0.98 & 1.92 \\
\hline $317-363$ & 1.00 & 1.00 & 1.03 & 1.00 & 0.98 & 1.87 \\
\hline
\end{tabular}

Prices received are 1973-1985 Arkansas auction prices. Prices are averaged over June through October to create a seasonal index calculated as the deviation from that average. Prices are reported in 1995 dollars using the USDA price index for production items, interest, taxes, and wage rates.

roughly corresponds to the period of the weather data (1972-1985) used for the GRAZE simulation. These price dataindexed to 1995 levels-were selected to capture potential seasonality inherent in the feeder price data which may have been linked to weather via factors such as pasture condition. Because the study objective was to isolate the impact of weather uncertainty on stocking rate performance, market risk other than seasonality in prices was not addressed. Consequently, the simulated selling price (PSELL) is the same from year to year for 2 steers of identical weight sold during the same week of the grazing.

Cost categories computed for each simulated scenario consisted of the purchase of the steer calf, costs associated with buying, selling, and hauling the animals, veterinary and medicine charges, a charge for interest on operating capital, and other miscellaneous charges (Table 2). The steer purchase price (226 kg @ $\$ 2.19 / \mathrm{kg}$ ) is the 13 year average May auction price (PBUY) for No. 1 medium-frame steers indexed to the 1995 price level. Veterinary costs, charges for buying and hauling, sales commission, and miscellaneous charges for death loss, salt, and minerals, etc., were based on Arkansas feeder cattle budgets (Flynn et al. 1992). Interest on operating capital was computed at an annual rate of $10 \%$ for the number of weeks the animals were actually carried. Only costs directly related to stocking rate were considered. Other costs incurred by the producer such as pasture establishment and maintenance, soil fertility, fencing, etc. are constant across all stocking rate treatments, and thus, were not explicitly accounted for in the analysis. Rather, they were implicitly included in the residual claimant, net returns to land, and overhead.

\section{Risk Analysis}

The 8 stocking rates were ranked for economic risk using generalized stochastic dominance (Meyer 1977a, 1977b), a research tool that separates possible strategies into those which are acceptable (i.e., dominant) from those which are rejected (i.e., inadmissable). Stochastic dominance can be used to evaluate strategies for a broad spectrum of decision maker attitudes ranging from risk averse to risk preferring, and hence the term "generalized." When using generalized stochastic dominance (GSD), the risk attitude of the decision maker is specified with a value called the PrattArrow risk aversion coefficient. These coefficients are either estimated or taken from empirical studies in the literature which categorize decision makers according to their risk attitude and level of risk tolerance. Although all Pratt-Arrow values are typically small (usually within the range -0.01 to +0.01 ), positive numbers always identify risk aversion, negative numbers indicate risk preference, and near-zero values characterize risk neutrality.
Table 2. Selected production and marketing costs for pastured stocker steers.

\begin{tabular}{ll}
\hline \hline Cost Category & Value \\
\hline Purchase steer calf & $226 \mathrm{~kg} @ \$ 2.19 / \mathrm{kg}$ \\
Death loss & $1.5 \%$ of purchase value $(\$ 7.43 / \mathrm{head})$ \\
Buying and hauling charge & $\$ 6.42$ per head \\
Veterinary/drug charge & $\$ 8.50$ per head \\
Salt and minerals & $\$ 0.67$ per head \\
Interest on operating capital & $10 \%$ per annum \\
Selling commission & $3 \%$ of gross receipts
\end{tabular}

${ }^{1}$ Calculated as: Interest charge $=$ Purchase price ${ }^{*}$ Interest rate ${ }^{*}($ Grazing period in weeks/52 wccks)

Moreover, a greater absolute value of the cocfficient indicates a greater magnitude or intensity of the corresponding risk attitude. By specifying a range of Pratt-Arrow values with upper and lower boundaries, the researcher "brackets in" a specific risk attitude and level of intensity to approximate the targeted audience of decision makers.

In addition to the specific levels of risk tolerance which the Pratt-Arrow coefficients identify, researchers who employ GSD often rank strategies for 2 other broadly defined risk attitudes which serve as benchmarks or "controls." First degree stochastic dominance (FSD) ranks strategies for all decision makers who simply prefer more returns to less-roughly speaking, profit maximizers who are unconcerned about risk, or at least, who have not specified their risk preference. Second degree stochastic dominance (SSD) is relevant for all decision makers who are risk averse without attempting to precisely designate the level of intensity - slight, moderate, or high — of risk aversion which they exhibit. FSD and SSD are relevant benchmarks because profit maximization and risk aversion are 2 characteristics which are typically assumed to be relevant for agricultural producers. In essence, both FSD and SSD are subsets of GSD, because they employ the same stochastic dominance method to rank strategies for 2 broadly defined classes of decision makers.

Four risk aversion intervals ranging between strong risk aversion and risk preference werc defined for this study based on empirical estimates of Pratt-Arrow values from the literature (Love and Robison 1984, Wilson and Eidman 1983). Scaling procedures suggested by Raskin and Cochran (1986) were employed in the ranking process in order to minimize the possibility of Type I error in identifying the risk efficient sets of strategies. Intervals approximating first degree (FSD) and second degree (SSD) stochastic dominance were also evaluated as benchmarks. The risk efficient set for each efficiency criterion identifies the stocking rate(s) which would be acceptable to decision makers whose risk attitudes conform to the restrictions specified by that criterion. Risk efficiency criteria and stochastic dominance ordering are discussed in detail in King and Robison (1984). Examples of the use of stochastic dominance in conjunction with biophysical models include Harris and Mapp (1986), and Parsch et al. (1991).

\section{Results and Discussion}

\section{Weight Gain and Economic Returns}

Table 3 provides selected sample statistics for simulated ani$\mathrm{mal} / \mathrm{crop}$ performance and net returns for the 8 stocking rates analyzed. The Table 3 sample means for weight gain per hectare 
Table 3. Summary statistics for the simulated beef-forage and economic performance at eight stocking rates over 14 years.

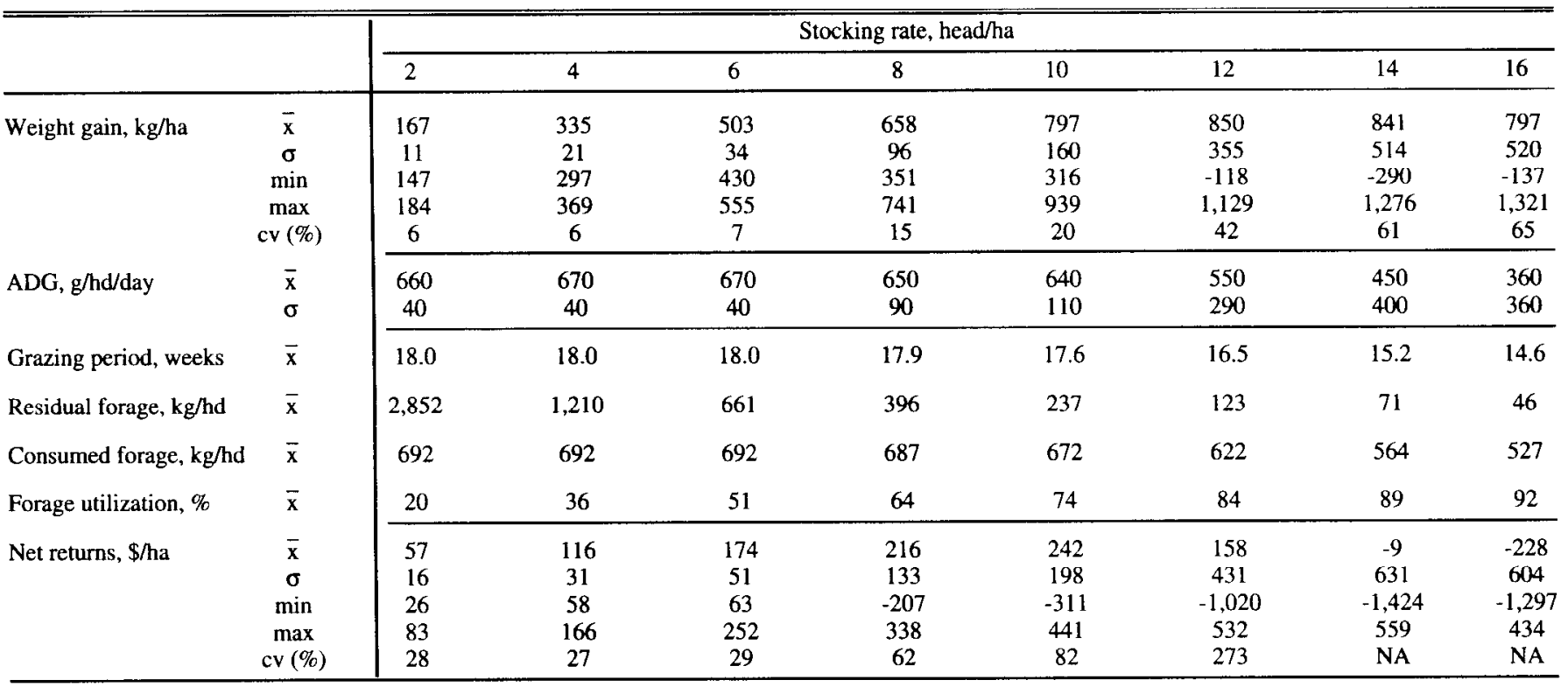

Notation: $\overrightarrow{\mathrm{x}}=$ sample mean; $\sigma=$ standard deviation; $\mathrm{cv}=$ coefficient of variation; and, min and max are the minimum and maximum values simulated over the 14 year period.

$(\mathrm{kg} / \mathrm{ha}), \mathrm{ADG}$ (g/hd/day), and net returns (\$/ha) for each of the 8 stocking rates are displayed graphically in Fig 3. At low stocking rates, daily weight gain per head is high (Fig. 3) because animals can selectively graze due to virtual lack of competition for forage. In addition, a plateau occurs in ADG at low stocking rates, i.e., less than $6 \mathrm{hd} / \mathrm{ha}$. This suggests that a "critical" stocking rate must be attained before there is sufficient competition for pasture to have a negative impact on individual animal performance. Below this critical level, stocking rate and ADG are independent, and weight gain per head is at, or near, maximum level. These simulated animal weight gain relationships concur with empirical research cited earlier in Peterson et al. (1965), Jones and Sandland (1974), Hart (1978), and Guerrero et al. (1984).

With higher stocking rates, increased grazing intensity reduces selective grazing and results in decreased average daily gains per steer (Table 3). Based on a field study, Hull et al. (1961) observed that, ". . . the forage consumed by the steers. . .decreased in quality [digestible energy] as the stocking rate increased. Heavier stocking rates force animals to consume more of the coarser portions of the forage. The steers on the more lightly grazed pastures could select a more nutritious diet." Subsequent observations by Hull et al. (1965) showed that with increased stocking rates ". . . the quantity of forage consumed per hectare increased, even though consumption per animal decreased. .." They attributed the resulting decreased production per animal to an "increased quantity of forage [being] utilized for maintenance of the animal rather than for gain." Increased consumption of forage dry matter per hectare is reflected in the simulated mean values of forage utilization (forage consumed/forage available) which ranged between $19.6 \%$ and $92.0 \%$ for the lowest and highest stocking rates, respectively (Table 3 ). Consistent with Hull et al. $(1961,1965)$, the simulation results also show a decrease in pasture consumption per head with a higher number of animals grazed. A meaningful measure of the degree of competition and the potential for sclectivity for each steer in the simulated sys- tems is provided in the mean values of residual forage at the end of each season (Table 3 ). At the critical stocking rate ( $6 \mathrm{hd} / \mathrm{ha}$ ), each steer has access to over 14 times as much forage $(661 \mathrm{~kg} / \mathrm{hd})$ as each steer in the $16 \mathrm{hd} / \mathrm{ha}$ system ( $46 \mathrm{~kg} / \mathrm{hd}$ ). Hence, the potential for grazing selectivity decreases with an increase in the number of animals.

Despite an inverse relationship between weight gain per head and stocking rate, the expected weight gain per hectare increases with the number of steers grazed and reaches a maximum at 12 hd/ha (Fig. 3). Reduced weight gain per animal at stocking rates between 6 and $12 \mathrm{hd} / \mathrm{ha}$ is more than compensated by increased weight gain per hectare.

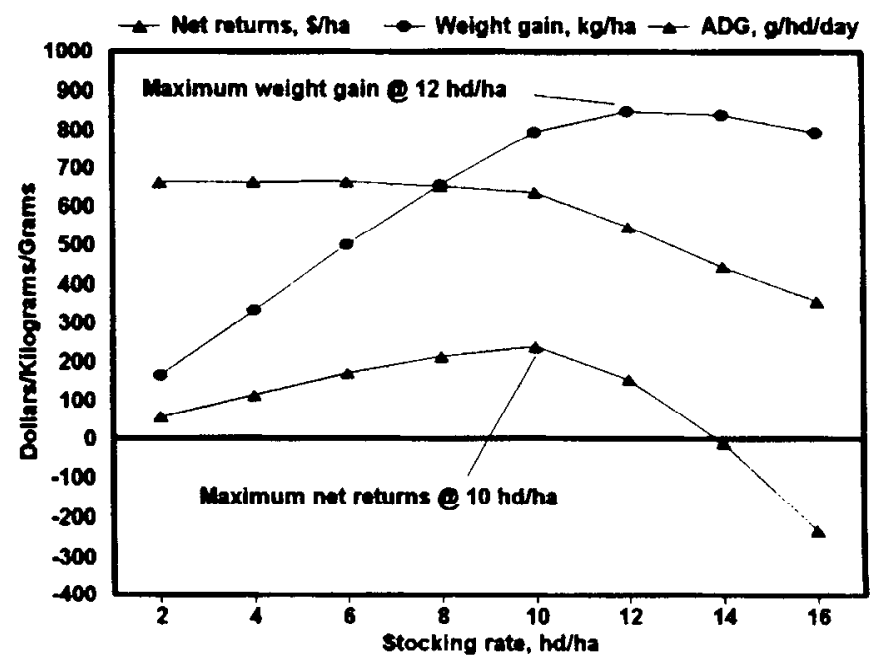

Fig. 3. Simulated mean net returns, weight gain, and ADG over 14 years. 
Mean net returns reach a maximum at $10 \mathrm{hd} / \mathrm{ha}$ which demonstrates that returns do not continue to increase with weight gain per hectare (Table 3 ). The decrease in expected net returns when stocking rate is increased beyond $10 \mathrm{hd} / \mathrm{ha}$ provides a classic example of how increased use of inputs (i.e. number of steers) reduces their marginal productivity - and hence value-to the point where the cost of the input outweighs its benefits. As stocking rate is increased, the simulated change in cost per additional steer in equation 1 is approximately constant. By contrast, simulated change in gross receipts per additional steer in equation 1 decreases as more animals compete for forage resulting in a reduced weight gain per head. Hence, obtaining the highest expected net returns per hectare balances a tradeoff between choosing lower stocking rates which make extensive use of pasture with high weight gain per head, and high stocking rates which are pasture intensive and lead to high weight gain per hectare.

\section{Impact of Weather Variability on Performance}

The differential impact of weather variability on the 8 stocking rates is evidenced by the sample standard deviations and maximum and minimum values of simulated weight gain and economic performance (Table 3). Most noteworthy is that, with one exception ( $16 \mathrm{hd} / \mathrm{ha}$ ), the variability of weight gain and net returns increases with stocking rate. Likewise, with higher stocking rates, minimum net returns are lower, and maximum net returns are higher than for corresponding minima and maxima at the lower stocking rates.

Inadequate precipitation or poor distribution of rainfall results in reduced pasture growth and diminished weight gain; these effects are magnified at high stocking rates. However, these same high stocking rates result in larger weight gain per hectare whenever weather is favorable. This is depicted graphically in Figure 4 which shows the simulated point of maximum livestock gain per hectare for 3 selected years representing droughty (1980), normal (1983), and high rainfall (1979) seasons. The stocking rate which supports the highest weight gain per hectare changes from year to year and is a function of weather (Fig. 4). Representative weather conditions permit the pasture to support only $6 \mathrm{hd} / \mathrm{ha}$ in droughty weather, but 12 or $14 \mathrm{hd} / \mathrm{ha}$ in normal or high rainfall years, respectively.

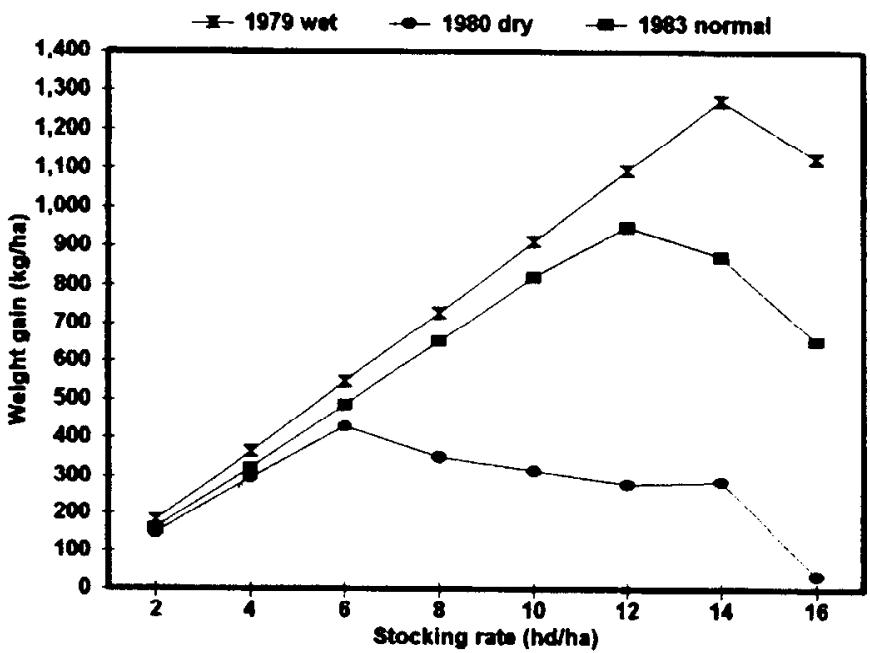

Fig. 4. Simulated weight gain for 3 representative years.
At the time the stocking decision is made, the issue for the manager of the stocker steer operation is to match the number of animals to be grazed with the weather scenario which provides sufficient herbage growth to support adequate gains and maximum net returns. With perfect knowledge, a producer might select a higher stocking rate in good years and a lower stocking rate in droughty years. In the absence of this knowledge, greater risk is incurred with higher stocking rates (Fig. 4). For example, at $6 \mathrm{hd} / \mathrm{ha}$ the pasture yields $547 \mathrm{~kg} / \mathrm{ha}$ weight gain if good weather prevails (1979) but only $430 \mathrm{~kg} / \mathrm{ha}$ in droughty conditions (1980). Corresponding net returns would be $\$ 239 / \mathrm{ha}$ and $\$ 63 / \mathrm{ha}$, respectively. By contrast, $12 \mathrm{hd} / \mathrm{ha}$ results in net returns of $\$ 482 / \mathrm{ha}(1,097 \mathrm{~kg} / \mathrm{ha}$ weight gain) in good weather, but the producer risks losing $\$ 451 /$ ha if droughty conditions similar to 1980 weather occur because weight gain would only be 280 $\mathrm{kg} / \mathrm{ha}$. The potential for magnified losses and gains at higher stocking rates is demonstrated statistically by enlarged confidence bands around simulated mean weight gain at the $90 \%$ and 99\% levels (Fig. 5). For example, an incrcasc in the stocking rate from 10 to 14 more than doubles the confidence interval for weight gain.

The sole exception to the increased risk with higher stocking rates is for the 16 head system (Table 3 ). The observed minimum weight gain $(-137 \mathrm{~kg} / \mathrm{ha})$ and minimum net returns $(\$-1,297 / \mathrm{ha})$ for the 16 head system occur in the 1972 weather year when precipitation during the early pasture growth period in May and June was lacking. Due to inadequate herbage, the steers lost in excess of 5\% of gross body weight and were sold at the end of week 3 (21 June) of the simulation. During the same year, steers in the 14 head system also lost weight, but at a slower rate. The threshold $5 \%$ wcight loss which initiates the early sell strategy was not triggered until the end of week 4 (28 June) of simulation. By that time, steers in the 14 head system had lost more weight $(-290$ $\mathrm{kg} / \mathrm{ha}$ ) causing even lower net returns $(\$-1,424 / \mathrm{ha})$ than under the 16 head system. Although lower returns with the 14 head system are in part due to increased interest charges for carrying the steers an additional week, this example demonstrates the importance of a default selling strategy on simulation results. Sample means for the number of weeks grazed (Table 3) show that stocking rates of 6 head or less grazed the full 18 week period for each of the 14 years simulated. Higher stocking rates were associated with

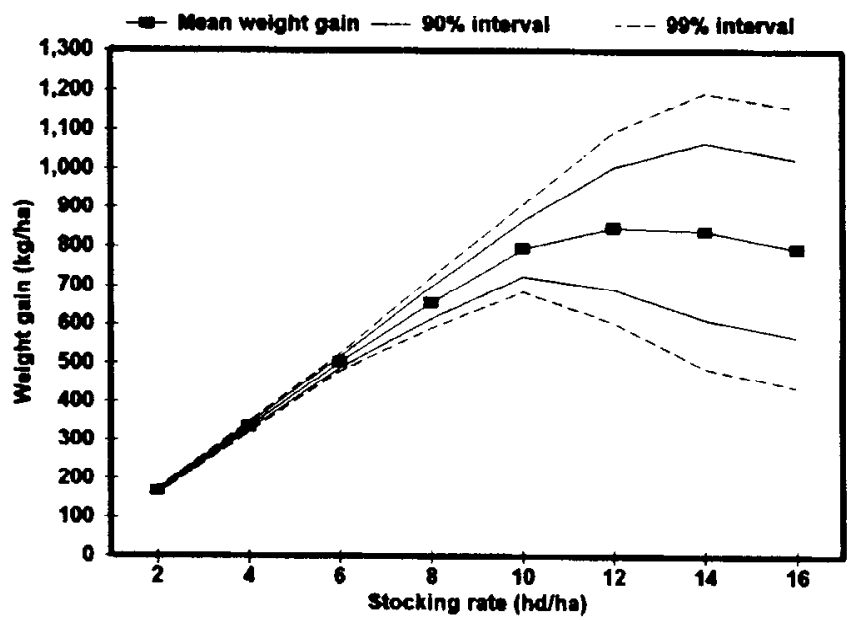

Fig. 5. Confidence intervals for mean weight gain at 8 stocking rates. 
increasingly shorter grazing periods per season. This is a function of the weight loss that occurs when pasture conditions can no longer support grazing.

An assessment of the differential impact of weather variability on net returns for 4 selected stocking rates demonstrates that the high stocking rate ( $12 \mathrm{hd} / \mathrm{ha}$ ) is shown to be the high risk strategy in that its economic performance is highly variable as a function of weather (Fig. 6). By contrast, net returns for the low stocking rate ( $6 \mathrm{hd} / \mathrm{ha}$ ) were little affected hy weather and hence, were relatively riskless. It is noteworthy that the ranking of the 3 strategies changes from 1 weather scenario to the next. In "good" years $(1974,1979,1981)$, higher stocking rates result in highest net returns whereas in "bad" years (1980) the converse is true and the rankings are reversed with low stocking rates earning the highest returns. In "intermediate" years $(1972,1976,1978)$ different rankings surface because weather and pasture condition affect the performance of some strategies but not others.

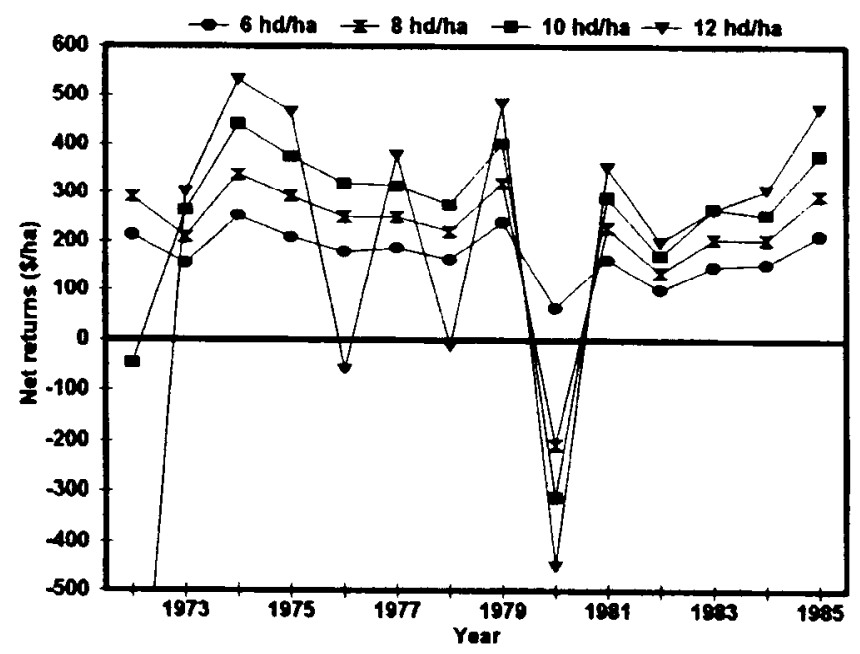

Fig. 6. Simulated net returns by year at 4 selected stocking rates.

\section{Risk Efficient Stocking Rates}

The information in Table 3 and Fig. 5 is important in that alternative decision makers will rank stocking rate strategies differently depending on their attitude toward risk. One necessary piece of information in the choice of a preferred strategy is an assessment of the unknown probabilities and distribution characteristics underlying each stocking rate strategy. An estimate of these distribution characteristics was obtained from simulated model output by developing an empirical distribution function (Hogg and Tanis 1977) of net returns for each of the 8 stocking rates. One of the major trade-offs with a high stocking rate (e.g., $14 \mathrm{hd} / \mathrm{ha}$ ) is that there is a relatively high probability (approximately 0.41 ) that returns to overhead in any given year will be negative (Fig. 7). By contrast, there is a 0.53 probability (i.e., $1.00-0.47$ in Fig. 7) that this same $14 \mathrm{hd} / \mathrm{ha}$ stocking rate will generate net returns in excess of the maximum simulated returns ( $\$ 252 / \mathrm{ha}$ ) attainable with the "critical" ( $6 \mathrm{hd} / \mathrm{ha}$ ) stocking rate. Likewise, a comparison between the stocking rate strategies which maximize weight gain (12 hd/ha) and net returns (10 $\mathrm{hd} / \mathrm{ha}$ ) shows that both the frequency and magnitude of losses with the 12 head strategy will exceed those of the 10 head strate- gy, but that returns with this same maximum weight gain strategy will exceed those of the profit maximizing strategy in about 9 years out of 14 .

Rankings of the 8 stocking rate strategies under FSD, SSD, and 4 specified risk attitudes using GSD are presented in Table 4 . The very low and the very high stocking rates $(2,4$, and $16 \mathrm{hd} / \mathrm{ha}$ ) were dominated by FSD and hence, would be inadmissible for decision makers who are solely profit maximizers with no specified risk attitude (Tahle 4). Stated alternatively, the FSD results imply that the producer who simply prefers more income to less would be irrational to stock at 2,4 , or $16 \mathrm{hd} / \mathrm{ha}$. CDFs for the 2 and 4 head strategies (not shown in Fig. 7) lie entirely to the left of the 6 head strategy; likewise, the 16 head CDF lies entirely to the left of the 12 head strategy. Thus, regardless of risk attitude, the remaining stocking rate strategies (the preferred set in Table 4 , i.e., $6,8,10,12$, or $14 \mathrm{hd} / \mathrm{ha}$ ) offer greater economic returns at all levels of probability.

Use of SSD reduces the size of the efficient set for producers who are risk averse to 3 strategies (Table 4) which include both the "critical" stocking rate ( $6 \mathrm{hd} / \mathrm{ha}$ ) and the strategy which maximizes expected net returns $(10 \mathrm{hd} / \mathrm{ha})$, but which excludes the maximum weight gain strategy ( $12 \mathrm{hd} / \mathrm{ha}$ ). Although expected net returns continue to increase with stocking rate for the 6,8 , and 10-head SSD set, Fig. 7 reveals a concurrent systematic decline in the lower bound of the CDF for these same strategies. Hence, SSD cannot further discriminate between these 3 strategies. Stated alternatively, it would be irrational for a producer who is risk averse to choose $2,4,12,14$, or $16 \mathrm{hd} / \mathrm{ha}$. Rather, the tradeoffs between higher risk for higher returns would be accommodated with either the 6,8 , or $10 \mathrm{hd} /$ ha stocking rate, but the final, actual choice of stocking rate would have to be made by the producer based on criteria which go beyond the scope of this stochastic dominance analysis.

The increased discriminatory power of GSD is evident for the non risk neutral efficiency criteria in Table 4. Producers who are either moderately or strongly risk averse will prefer to stock at 6 $\mathrm{hd} / \mathrm{ha}$ as the "best" or preferred strategy and avoid the adverse effects that could be encountered in a poor weather season. By

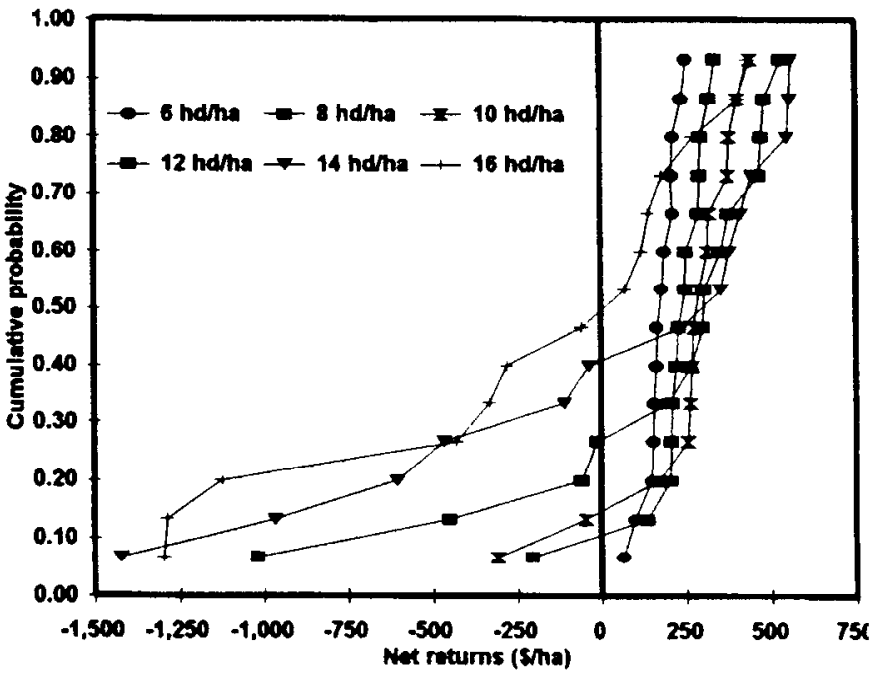

Fig. 7. Cumulative distribution functions for 6 selected stocking rates. 
Table 4. Ranking of steer stocking rate strategies for alternative risk attitudes'.

\begin{tabular}{|c|c|c|c|}
\hline \multirow{2}{*}{ Risk Attitude } & \multicolumn{2}{|c|}{ Risk Interval ${ }^{2}$} & \multirow{2}{*}{$\begin{array}{c}\text { Preferred } \\
\text { Stocking } \\
\text { Rate Strategy }\end{array}$} \\
\hline & Lower Bound & Upper Bound & \\
\hline FSD (no restriction) & -0.0010 & 0.0010 & $6,8,10,12,14$ \\
\hline SSD (all risk aversion) & 0.0000 & 0.0010 & $6,8,10$ \\
\hline Strong risk aversion & 0.0004 & 0.0010 & 6 \\
\hline Moderate risk aversion & 0.0001 & 0.0004 & 6 \\
\hline Risk neutral & -0.0001 & 0.0001 & $6,8,10,12,14$ \\
\hline Risk preferring & -0.0008 & -0.0001 & 14 \\
\hline
\end{tabular}

${ }^{A}$ All rankings were calculated for an 81 ha farming operation, an average area of improved and cropland pasture per farm representative of Logan County, Arkansas. based on a scaling procedure described by Raskin and Cochran (1986).

${ }^{2}$ Lower and upper bound Pratt-Arrow coefficients of absolute risk aversion.

${ }^{3}$ Risk efficient set of stocking rate strategies, hd/ha.

contrast, strongly risk preferring producers will be attracted to a high stocking rate (14 hd/ha) which exhibits lower expected returns than the 10 head profit maximizing strategy, but which results in greater returns in 7 years out of 14 . Other producers, whose attitudes toward risk are neutral, however, might choose any 1 of the 5 stocking rates identified for the FSD set.

\section{Conclusion}

This study uses a biophysical simulation model GRAZE to analyze the impact of weather variability on the economic performance of 8 stocking rate strategies for a stocker steer grazing system. Based on 14 years of simulated output, the results indicate that: (a) expected weight gain per head was largely independent of grazing intensity until a critical stocking rate (6 hd/ha) was attained; (b) the highest expected weight gain per hectare was achieved under a higher ( $12 \mathrm{hd} / \mathrm{ha}$ ) stocking rate than one which resulted in highest expected net returns (10 hd/ha); (c) an increase in the stocking rate was accompanied by greater production (weather) risk which was reflected in increased variance of weight gain and net returns as well as a higher frequency and magnitude of economic losses; and, (d) non neutral attitudes toward risk-i.e, either risk averse or risk preferring producerswould be consistent with preferred strategies ranging between 6 head (strong risk aversion) and 14 head (risk preferring) based on stochastic dominance ordering.

The use of a biophysical model such as GRAZE permits the livestock/pasture researcher to address a variety of production management strategies whose economic success is in part affected by subtle dynamic interactions between plant and animal. The study has thus attempted to respond to Scarnecchia's (1994) demand for research which addresses the multiple, complex relationships of livestock grazing. In an attempt to focus on production management and weather risk, certain issues relevant to the stocker steer producer have been ignored in the design of this computer experiment. These issues include many additional production management alternatives which would normally be available to the producer (e.g., supplemental feeding whenever pasture is deficient in a droughty year; production of hay on undergrazed pasture or whenever there is surplus forage; extension of the grazing period when herbage is adequate, pasture irrigation, etc.) as well as consideration of a host of marketing strategies which no producer can overlook. Likewise, because this simulation study treats years as independent observations, i.e., replicates in time, the potential for analyzing the long-term impact of high stocking rates on pasture depletion or sustainability is ignored. Regardless of these exclusions, this study demonstrates that biophysical models used in conjunction with stochastic dominance are useful tools in assessing production risk in livestock agriculture.

\section{Literature Cited}

Adjei, M.B., P. Mislevy, and C.W. Ward. 1980. Response of tropical grasses to stocking rate. Agron. J. 72:863 868 .

Aiken, G.E. and D.I. Bransby. 1992. Technical note: stocking equivalents and stocking rate-gain relationships for steers and cow-calf pairs grazing oversown bermudagrass. J. of Anim. Sci. 70:3234-3237.

Antoni M., R. Ramos, A. Casas, and E. Marrero. 1992. Determination of economic stocking rates for beef cattle stargrass under two fertilizer levels. J. of Agr. of the Univ. of Puerto Rico 76:131-150.

Bement, R.E.. 1969. A stocking rate guide for beef production on blue grama range. J. Range Manage. 22:83-86.

Bertelsen, B.S., D.B. Faulkner, D.D. Buskirk, and J.W. Castree. 1993. Beef cattle performance and forage characteristics of continuous, 6-paddock and 11-paddock grazing systems. J. Anim. Sci. 71:1381-1389.

Carande, V.G., E.T. Bartlett, and P.H. Gutierrez. 1995. Optimization of rangelands management strategies under rainfall and price risks. J. Range Manage. 48:68-72.

Chapman, H.D., W.H. Marchant, P.R. Utley, R.E. Hellwig, and W.G. Monson. 1972. Performance of steers on Pensacola bahiagrass, Coastal bermudagrass, and Coastcross- 1 bermudagrass pastures and pellets. J. Anim. Sci. 34:373-78.

Conrad, B.E., E.C. Holt, and W.C. Ellis. 1981. Steer performance on Coastal, Callie, and other hybrid bermudagrasses. J. Anim. Sci. 53:1188-1192.

Curll, M.L. 1978. Simulation: an aid to decisions on superphosphate use for beef production. Agr. Systems 3:195-204.

Flynn, A.G., C.R. Garner, and J.W. Goodwin. 1992. Feeder cattle production budgets for Arkansas, 1992. Univ. of Ark. Coop. Ext. Service, ETB 205, Little Rock, Ark.

Guerrero, J.N., B.E. Conrad, E.C. Holt, and H. Wu. 1984. Prediction of animal performance on bermudagrass pasture from available forage. Agron. J. 76:577-80.

Halls, L.K. 1957. Grazing capacity of wiregrass pine ranges of Georgia. J. Range Manage. 10:1-5.

Harlan, J.R. 1958. Generalized curves for gain per head and gain per acre in rates of grazing studies. J. Range Manage. 11:140-47.

Harris, T.R. and H.P. Mapp. 1986. A stochastic dominance comparison of water conserving irrigation strategies. Amer. J. Agr. Econ. 68:298-305.

Hart, R.H. 1972. Forage yield, stocking rate, and beef gains on pasture. Herbage Abstracts 42:345-53.

Hart, R.H. 1978. Stocking rate theory and its application to grazing on rangelands. p. 547-550. In: D.N. Hyder (ed.) Proc. of the First Int. Rangeland Congr., 14-18 Aug. 1978, Denver, Colo.

Hart, R.H. 1989. SMART: a simple model to assess range technology. J. Range Manage. 42:421-424.

Hart, R.H. 1993. "Invisible colleges" and citation clusters in stocking rate research. J. Range Manage. 46:378-382.

Hart, R.H., J.W. Waggoner, T.G. Dunn, C.C. Kaltenbach, and L.D. Adams. 1988. Optimal stocking rate for cow-calf enterprises on native range and complementary improved pastures. J. Range Manage. $41: 435-441$.

Heitschmidt, K.K. and C.A. Taylor. 1991. Livestock production. In R.K. Heitschmidt and J.W. Stuth (eds.) Grazing Management: An Ecological Perspective. Timber Press, Portland Ore.

Hildreth, R.J. and M.E. Riewe. 1963. Grazing production curves. II. Determining the economic optimum stocking rate. Agron. J. $55: 370-72$

Hogg, R.V. and E.A. Tanis. 1977. Probability and Statistical Inference. (Ch. 3). Macmillan Publishing Co., New York, N.Y. 
Holechek, J.L., R.D. Pieper, and C.H. Herbel. 1995. Range Management: Principles and Practices. Prentice Hall, Englewood Cliffs, N.J.

Hubbard, W.A. 1951. Rotational grazing studies in Western Canada. J. Range Manage. 4:25-29.

Huffaker, R.G. and J.E. Wilen. 1991. Animal stocking under conditions of declining forage nutrients. Amer. J. Agr. Econ. 73:1213-1223.

Hull, J.L., J.H. Meyer, and R. Kromann. 1961. Influence of stocking rate on animal and forage production from irrigated pasture. J. Anim. Sci. 20:46-52.

Hull, J.L., J,H. Meyer, S. Bonilla, and W. Weitkamp. 1965. Further studies on the influence of stocking rate on animal and forage production from irrigated pasture. J. Anim. Sci. 24:697-704.

Jones, R.J. and R.L. Sandland. 1974. The relation between animal gain and stocking rate. J. Agr. Sci. Cambridge 83:335-42.

King, R.P. and L.J. Robison. 1984. Risk efficiency models. In: P.J. Barry (ed.) Risk Management in Agriculture. Iowa State Univ. Press, Ames, Iowa.

Knight, J.C., M.M. Kothmann, G.W. Mathis, and R.T. Hinnant 1990. Cow-calf production with alternative grazing systems. J. of Prod Agr. 3:407-414

Love, R.O. and L.J. Robison. 1984. An empirical analysis of the intertemporal stability of risk preference. South. J. Agr. Econ. 16:159-165.

Loewer, O.J. and L.D. Parsch (eds.) 1995. GRAZE Beef-Forage Simulation Model: Case Studies. South. Coop. Series Bull. 381B Univ. of Ark., Fayetteville, Ark.

Loewer, Otto J., K.L. Taul, L.W. Turner, N. Gay, R. Muntifering. 1987. GRAZE: A model of selective grazing by beef animals. Agr. Systems 25:297-309.

Loewer, O.J., W. Butts, S.W. Coleman, L.L. Erlinger, H.W. Essig, J.P. Fontenot, N. Gay, A.C. Linnerud, C. Long, R. Muntifering, J. Oltjen, D.G. St. Louis, J.A. Stuedemann, K.L. Taul, and L.W. Turner. 1985. The animal component. In: V.H. Watson and C.M. Wells, Jr. (eds.) Simulation of Forage and Beef Production in the Southern Region. South. Coop. Series Bull. 308, Miss. State Univ., Miss. State, Miss

Meyer, J. 1977a. Second degree stochastic dominance with respect to a function. Int. Econ. Rev. 18:477-487.

Meyer, J. 1977b. Choice among distributions. J. Econ. Theory $14: 326-336$

Neville, W.E. and W.C. McCormick. 1976. Production of beef calves on Coastal bermuda grass at two levels of grazing intensity: costs and returns. J. Anim. Sci. 42:1404-1412.

Olowolayemo, S.O., J.C. Reeves, J.C. Martin, N.R. Martin Jr., R.R. Harris, and D.I. Bransby. 1992. Economics and efficiency factors for optimal stocking rate. Auburn Univ. Agr. Exp. Sta. Highlights of agricultural research 39:12.

Parsch, L.D. and O.J. Loewer (eds.) 1995. GRAZE Beef-Forage Simulation Model: User Guide. South. Coop. Series Bull. 381 A, Univ. of Ark., Fayetteville, Ark.

Parsch, L.D., M.J. Cochran, K.L. Trice, and H.D. Scott. 1991. Biophysical simulation of wheat and soybean to assess the impact of timeliness on double cropping economics. p. 511-534 In: J. Hanks and J.T. Ritchie (eds.) Modeling Plant and Soil Systems, Agron. Monogr. 31, ASA-CSSA-SSA, Madison, Wisc.

Pearson, H.A. 1973. Calculating grazing intensity for maximum profit on ponderosa pine range in Northern Arizona. J. Range Manage. 26:277-278.

Peterson, R.G., H.L. Lucas, and G.O. Mott. 1965. Relationship between rate of stocking and per acre and per animal performance on pasture. Agron. J. 57:20-30.

Raskin, R. and M.J. Cochran. 1986. Interpretations and transformations of scale for the Pratt Arrow absolute risk aversion coefficient: implications for generalized stochastic dominance. West. J. Agr. Econ. 11:204-210.

Riechers, R.K., J.R. Conner, and R.K. Heitschmidt. 1989. Economic consequences of alternative stocking rate adjustment tactics: a simulation approach. J. Range Manage. 42:165-171.
Riewe, M.E. 1961. Use of the relationships of stocking rate to gain of cattle in an experimental design for grazing trials. Agron. J. 53:309-313.

Riewe, M.E., J.C. Smith, J.H. Jones, and E.C. Holt. 1961. Grazing production curves I: Comparison of steer gains on Gulf ryegrass and tall fescue. Agron. J. 55:367-369.

Rodriguez, A. and R.G. Taylor. 1988. Stochastic modeling of shortterm cattle operations. Amer. J. Agr. Econ. 70:121-132.

Rowan, R.C., L.D. White, and J.R. Conner. 1994. Understanding cause/effect relationships in stocking rate change over time. J. Range Manage. 47:349-354.

Russell, K.D., R. Hironaka, and D.B. Wilson. 1981. An economic analysis of alternative management techniques for beef production on irrigated pastures in Alberta. Canadian Farm Econ. 16:1-17.

Scarnecchia, D.L. 1994. A viewpoint: using multiple variables as indicators in grazing research and management. J. Range Manage. 47:107-111.

Smith, E.M., L.M. Tharel, M.A. Brown, G.W. Burton, C.T. Dougherty, S.L. Fales, V.H. Watson, and G.A. Pederson. 1985. The plant growth component. In: V.H. Watson and C.M. Wells, Jr. (eds.) Simulation of Forage and Beef Production in the Southern Region. South. Coop. Series Bull. 308, Miss. State Univ., Miss. State, Miss.

Torell, L.A., K.S. Lyon, and E.B. Godfrey. 1991. Long-run versus short-run planning horizons and the rangeland stocking rate decision. Amer. J. Agr. Econ. 73:795-807.

USDA-AMS Agricultural Marketing Service, (Livestock, Poultry, Grain, and Seed Division), Livestock detailed annual quotations, Little Rock, Ark.

White, F.C. and V.R. Eidman. 1971. The Bayesian decision model with more than one predictor-an application to the stocking rate problem. South. J. Agr. Econ. 3:95-102.

Willms, W.D., S. Smoliak, and G.B. Schaalje. 1986. Cattle weight gains in relation to stocking rate on rough fescue grassland. J. Range Manage. 39:182-186.

Wilson, P.N. and V.R. Eidman. 1983. An empirical test of the interval approach for estimating risk preferences. West. J. Agr. Econ. 8:170-182.

Workman, J.W. 1986, Range Economics. Macmillan Publishing Co., New York, N.Y. 